\title{
Spray Drying for the Encapsulation of Oils-A Review
}

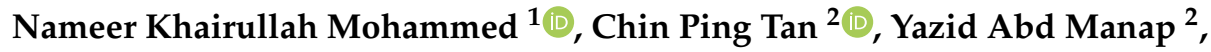 \\ Belal J. Muhialdin 2,3 (D) and Anis Shobirin Meor Hussin 2,3,* \\ 1 Department of Food Science, Faculty of Agriculture, Tikrit University, Tikrit 34001, Iraq; nameer@tu.edu.iq \\ 2 Faculty of Food Science and Technology, Universiti Putra Malaysia, Serdang, Selangor 43400, Malaysia; \\ tancp@upm.edu.my (C.P.T.); myazid@upm.edu.my (Y.A.M.); belal@upm.edu.my (B.J.M.) \\ 3 Halal Products Research Institute, Universiti Putra Malaysia, Serdang, Selangor 43400, Malaysia \\ * Correspondence: shobirin@upm.edu.my; Tel.: +60-3-8946-8347; Fax: +60-3-8942-3552
}

Received: 18 July 2020; Accepted: 13 August 2020; Published: 26 August 2020

\begin{abstract}
The application of the spray drying technique in the food industry for the production of a broad range of ingredients has become highly desirable compared to other drying techniques. Recently, the spray drying technique has been applied extensively for the production of functional foods, pharmaceuticals and nutraceuticals. Encapsulation using spray drying is highly preferred due to economic advantages compared to other encapsulation methods. Encapsulation of oils using the spray drying technique is carried out in order to enhance the handling properties of the products and to improve oxidation stability by protecting the bioactive compounds. Encapsulation of oils involves several parameters-including inlet and outlet temperatures, total solids, and the type of wall materials-that significantly affect the quality of final product. Therefore, this review highlights the application and optimization of the spray drying process for the encapsulation of oils used as food ingredients.
\end{abstract}

Keywords: spray drying; encapsulation; oils; wall material; food ingredients

\section{Introduction}

Modern consumers are concerned about their health, and this concern leads to a high demand for foods that contain bioactive or functional ingredients (especially natural ones) that increase the nutritional value and health status of food [1]. In particular, there is a growing demand for nutritious and healthy oils in the food, pharmaceutical, and cosmetic industries due to their multi-functional properties. Nevertheless, due to their high level of unsaturation, vegetable and marine oils are prone to oxidation deterioration in addition to the resulting production of unpleasant taste. Moreover, oils are unstable under processing and storage conditions due to their sensitivity to light and heat, which limits their application in the food industry. Hence, it is necessary to protect the oils to improve their stability during handling, processing, and storage [2,3]. These fluctuations negatively affect the developed products in terms of their shelf-life, sensory properties, and overall acceptability [4]. Encapsulation is a promising approach that is widely used to overcome the above-mentioned problems by protecting the core materials from heat, light and oxygen, thus promoting stability, increasing bioavailability, flavour-masking, and controlled release, while maintaining the oils' functional properties and increasing their ease of handling [5]. Encapsulation can be defined as a process for entrapping one substance (termed the core material or active agent) within another substance (the coating, shell, or carrier/wall material). Encapsulation using spray drying is a reliable technique in the food industry that has been successfully used to overcome these challenges [6,7]. Microencapsulation technology is becoming a common technology used with oils around the world, such as microencapsulated palm oil, microencapsulated fish oil, and microencapsulated coconut oil, which are used as food ingredients. 
Encapsulation may enhance ease of handling, adequacy of concentration and uniformity of dispersion [8]. Despite the rapid drying contact time (several seconds) of the core materials in the drying chamber, spray dryers have high drying temperatures, typically with an input air temperature of 150 to $250{ }^{\circ} \mathrm{C}$, and an outlet air temperature of $50-80{ }^{\circ} \mathrm{C}$ [9]. The resulting particles range from a few nanometers to a few hundred micrometers [10]. The structural type and desired size generally depend on the preparation method and the wall materials applied [11]. The application of encapsulation in food production requires the wall materials to be of food grade and have protective properties for the core materials against external factors. The carrier materials typically used for oil encapsulation include synthetic polymers and natural biomaterials (commonly carbohydrates and proteins) [12]. Therefore, this review focus on the principles, wall materials, and processing parameters of spray drying for oils encapsulation. In addition, this review illustrates recent research on oil encapsulation through spray drying and the application of these products in foods.

\section{Oil Encapsulation Benefits}

Encapsulation of oils improves the oxidative stability of their lipids and protects sensitive constituents (core) such as active compounds, oils, flavour compounds, and vitamins from environmental factors. This facilitates high solubility and easy mixing of the core material, and manages the release of the core material in order to attain an appropriate delay until the appropriate stimulus. Moreover, it reduces the evaporation of volatile compounds in the core material, masking or covering any unpleasant tastes associated with the core material [13-16]. The reasons for applying encapsulation for oils can be summarized as follows:

(a) Improvement of the oxidative stability of lipids by applying the encapsulation process to produce powdered edible oil products, helping to prolong shelf-life by protecting oils from oxidation [14].

(b) Shielding of core materials, which are usually sensitive compounds such as oils, flavours, and vitamins, from oxygen, light, or water. In general, food oils exhibit significant susceptibility to light, temperature, air, and irradiation $[17,18]$.

(c) Alteration of the oils from a liquid to a dry form in order to produce powder with high solubility and acceptable mixing properties of the core materials. Conversion of the fluid feed (flavours and edible oils) into powders in solid form with desirable handling properties is an important use of encapsulation in the food industry [19].

(d) Managing the release of the core material in order to achieve a suitable delay for the proper stimulus; a vital benefit of the encapsulation of oils and flavours is control over the release time of the active ingredients until they have arrived at their target [20].

(e) Preventing evaporation of volatile compounds in the core materials. The dry powder obtained through the encapsulation process possesses high oxidation stability and reduced volatility. The encapsulation of oils results in a dry powder with improved oxidation and less volatility, which simplifies its application in various end-products such as cakes and beverages [21].

(f) Masking or covering the unpleasant tastes of the core material. The incorporation of some edible oils, such as vegetable oils or marine oils, in food products is in high demand due to the nutritional value of these products [16]. In addition, encapsulation can also help to overcome the main problems associated with food containing 3 PUFA, the unpalatable "fishy" flavour of fish oil, and the susceptibility of polyunsaturated fatty acids to oxidation, has all of which have a negative impact on food acceptability $[16,22]$. Encapsulation positively affects the stability and resistance of oils under storage conditions in comparison to oils without encapsulation [23].

\section{Encapsulation Using the Spray Drying Technique}

Encapsulation is a technique whereby small particles or droplets of active substances that have several attractive characteristics are enclosed within a coating in order to protect them against environmental factors such as oxygen, light, moisture and interactions with other compounds. 
Encapsulation is typically used to obtain particles with a diameter of 1-1000 $\mu \mathrm{m}$ of food ingredients or other materials. In addition, this technique can enable the controlled release of the encapsulated core when certain conditions are met [24]. Encapsulation using a spray dryer has frequently been used for food production on an industrial scale since the late 1950s, primarily for fats and oils, and flavourings and colourings [25]; see Table 1. Moreover, encapsulation is widely used in the food industry to incorporate oil aromas in a spray-dried form, because it is inexpensive, flexible, can be used in continuous operation, and produces particles of good quality [5]. The process can be conducted by changing the slurry emulsion from a liquid form into a powder in a continuously operating procedure. The basic principle of this method is to dissolve the core/wall materials in water to prepare an emulsion in liquid form, and then to feed this emulsion into a hot medium $\left(100-300{ }^{\circ} \mathrm{C}\right)$ to evaporate the water. The final dried product can be collected in powder form, or as agglomerated particles, depending on the nature of the materials used in the feed, the design of the dryer's operation, and the operating conditions. The high temperature of the drying chamber facilitates the water evaporation from the droplets [26]. Despite the energy used in the spray-drying process in terms of heat, spray drying has been shown to be more efficient than freeze drying for the encapsulation of oils, with a 30-50 times lower cost [27]. This technique does, however, require high-temperature conditions and access to air. Although the temperature of the spray dryer is high, the wet-bulb only requires a short duration of exposure (few seconds), and water vaporization will take place in the range of 30 to $50{ }^{\circ} \mathrm{C}$ [28]. A schematic diagram of the encapsulation process using the spray drying technique is presented in Figure 1. According to Bakry et al. [18], encapsulation using spray-drying consists of four main stages: (i) preparation of a stable emulsion; (ii) homogenization of the dispersion; (iii) atomization of the emulsion; and (iv) dehydration of the atomized particles. Typically, the first stage is carried out by dissolving the wall materials in distilled water and emulsifying, or dispersing using a magnetic stirrer overnight at $25{ }^{\circ} \mathrm{C}$ to ensure full saturation of the polymer molecules, and to prevent any variations caused by temperature changes. Before starting the second stage, core materials mixed with an aqueous solution of the wall materials and then the emulsifying agent can be added, depending on the emulsifying characteristics of the wall materials. The formed emulsion containing the wall materials and the core substances must be stable until the drying stage [29].

\section{Unit Operation of Spray Drying}

The process of spray drying is illustrated in Figure 1. The steps of the spray drying process involve: (a) atomization of fluid feed; (b) drying of the medium; (c) drying of the feed and spray contact; and (d) separation of the product from air. The properties of the final product are directly influenced by all of the steps, including their operational parameters. Spray drying is a very rapid and reproducible drying method, due to the very large surface area created by the atomization of the liquid feed [30].

\subsection{Feed Atomization}

Atomization involves converting the fluid feed (emulsion) into small droplets of uniform size resulting in a balance of heat and mass transfer in the drying stage, as well as increasing the surface area and allowing a good distribution of the feed within the dryer chamber. The size enlargement of the particles (surface area) leads to fast water evaporation and formation of a crust, drying the feed in seconds. Different types of atomizers, including rotary atomizers, pressure nozzles, pneumatic nozzles and sonic nozzles, exist to accomplish feed liquid collapse [30]. To choose the atomizer type based on the feed needing to be converted to dried powder and also on the desired particle size of the final product. 


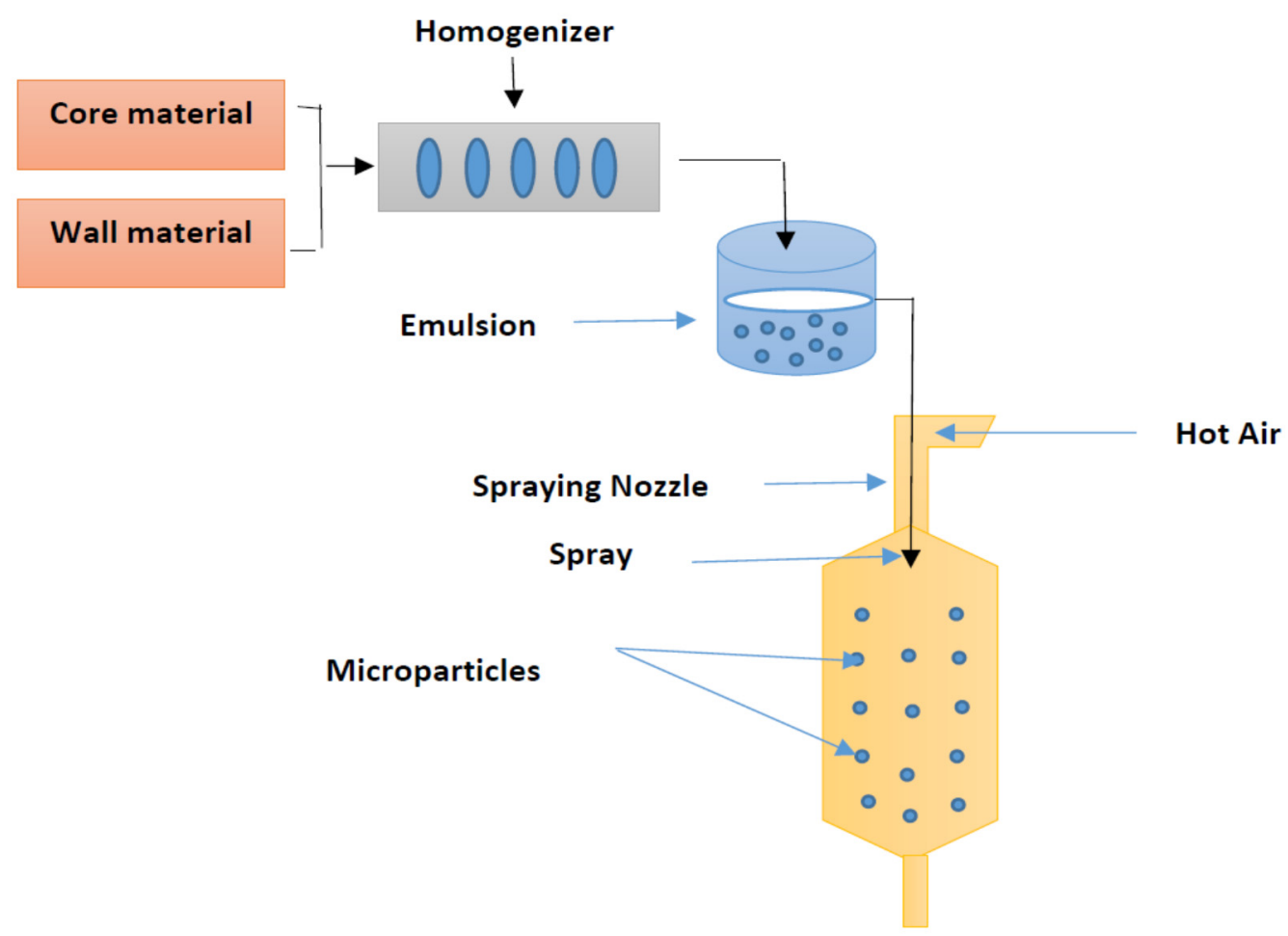

Figure 1. Schematic representation of the encapsulation process by spray-drying.

\subsection{Air Flow Contact}

Air flow contact is influenced by the fluid spray and the air contact time, because both factors determine the drying rate and the intensity of the drying. At this stage, the air flow contact starts from the drying step and continues during atomization. The atmosphere inside the heating chamber of the spray dryer is controlled by the operating parameters of the air heating and filtration system. The gas used during the process is usually nitrogen or another gas chosen based on the sensitivity or instability of the feed in the presence of oxygen [30]. In general, two types of feed-drying air flow conditions are available:

(a) The co-current drying design: in this configuration, the atomizer is located in the top of the drying chamber along with the drying gas stream inlet. The feed is sprayed in the same direction as the hot air, and thus it is preferred for heat sensitive composites. The inlet temperature is usually $150-220^{\circ} \mathrm{C}$ and rapid vaporization takes place; the outlet temperature is $50-80^{\circ} \mathrm{C}$, which limits the thermal degradation. This design exposes heat-sensitive materials to the lower exit air temperature only.

(b) The counter-current drying design: this system is not popular and has limited applications for dry products. The emulsion and the drying air are introduced at opposite ends of the dryer. Although this configuration is more thermally efficient than the co-current drying design as it exposes the dried powders to high temperatures, it has limited use for products that are sensitive to heat. As a result, of the complicated flow, the drying phenomena are not clear in these systems [29,31].

\subsection{Drying and Particle Formation}

The third step is drying and particle formation by convection. The heat is transferred from the drying medium to the droplets, where it is converted to latent heat during evaporation of moisture content from the droplets. The temperature and mass transfer rate are based on the diameter of the droplets and the relative velocity of the air and the droplets. Quick moisture evaporation immediately happens when the droplets come into contact with the drying air. Initially, the droplet surface exhibits a continuous mass transfer of moisture from within the droplet. At last, a dried shell is formed and moisture evaporation continues at a slower rate until the final product is formed $[29,30]$. 


\subsection{Separation of Product from the Drying Air}

The last step involves the separation of the product from the drying air. The spray drying begins when the dried particles fall to the bottom of the drying chamber and are collected through gravitational effects; while fines entrained in the drying air are parted from the atmosphere and separation occurs after the dried particles recovered in a cyclone filter that is located outside the dryer with collection bottle [29]. The liquid emulsion consists of the wall and core materials and is converted through the spray drying process into dried particles in powder form. The dried particles are spherical in shape with a size range from 10 to 100 micrometres [32].

\section{Optimizing the Encapsulation Process Conditions}

To obtain high encapsulation efficiency and the desired particle quality, the spray drying parameters should be optimized, even if the coating material is appropriate. The encapsulation efficiency is directly influenced by the characteristics of the wall/core materials, the properties of the in feed emulsion and the parameters of the spray drying process, including inlet/outlet air temperature, humidity, air flow rate and the type of atomization [33].

\subsection{Inlet and Outlet Temperatures}

To obtain a final product with a high yield and degree of encapsulation, the inlet and outlet air temperatures should be optimized, and the feed emulsion should be stable throughout the processing time [34]. In general, the inlet air temperature is in the range of $150-220^{\circ} \mathrm{C}$ and evaporation occurs instantaneously. The low air inlet temperature results in a low evaporation rate, which leads to microcapsules with high-density membranes, high moisture content, low fluidity, and ease of agglomeration. Therefore, the particles will easily stick to the internal wall of the drying chamber, resulting in a low yield. However, too high an inlet temperature results in extreme vaporization, and membrane cracks may occur, and subsequently premature release and degradation or loss of encapsulated cores [29]. According to Carmona [35], optimizing the encapsulation of palm fibre oil by spray drying and the range of inlet air temperature was $\left(130-202{ }^{\circ} \mathrm{C}\right)$. The optimum inlet temperature was found to be $166^{\circ} \mathrm{C}$. Recently, Basyiğit, B., et al. studied the effect of inlet air temperature $\left(120-220^{\circ} \mathrm{C}\right)$ on the properties of sour cherry oil encapsulated using spray drying [36]. The researcher observed that higher inlet air temperature positively affected the flowability and the optimal temperature was $195^{\circ} \mathrm{C}$. The author suggested that the effects were due to the wide range of inlet and outlet temperatures reported, which is considered to be a crucial parameter in the spray drying process to have particles with stable characteristics.

\subsection{Total Solids of the Emulsion}

The total solids concentration refers to the (wall material + oil) ratios in the emulsion calculated and represented on a dry basis. Jafari et al. [15] reviewed a variety of previous studies that optimized total solids in the emulsion for encapsulation. The review recommended maximum feed solid content to be applied. However, other studies suggested that the optimum feed solid content should be used for food flavours and oils due to two facts: first, using high content of wall material overrides solubility. Hence, un-dissolved wall materials will not improve the encapsulation process and will result in lower flavour retention for the dried particles. The second reason is to achieve the optimum emulsion, which is correlated with the viscosity of the primary emulsion. The character of the core material affected the emulsion content of the total solids. The total solid content has a pronounced influence on the core materials that are most susceptible to loss, like volatile compounds, as well as the efficiency of encapsulation. Recently, Frascareli et al. [37] studied the encapsulation process conditions of coffee oil encapsulated by spray drying, and the optimized total solids was $30 \%$. In another study, by Carmona [35], the effect of total solid content (20-40\%) on characteristics of spray-dried palm fibre oil was investigated, and the optimum solid content was $35 \%$. 
In addition, $\mathrm{Ng}$ et al. [38] demonstrated that $40 \%$ total solid content (wall/oil) was the most effective formulation for the encapsulation efficiency (MEE) and the oxidative stability of encapsulated kenaf seed oil. Moreover, the optimum total solid reported by [36] was found to be $20 \%$ for the sour cherry oil encapsulated by spray drying when optimization was conducted with the range of total solid (16.59-33.41\%). Therefore, total solid concentration is a very important factor that needs to be covered when obtaining encapsulated oils with desired properties. Table 1 summarizes the optimization of encapsulation conditions of several oil sources. The optimized spray-drying conditions for various ingredients within different wall materials were shown to be different. The total solids were in the range $20-40 \%$. Moreover, the range of the inlet air temperatures was $135-202{ }^{\circ} \mathrm{C}$.

Table 1. Optimization of spray drying process conditions for various types of oils.

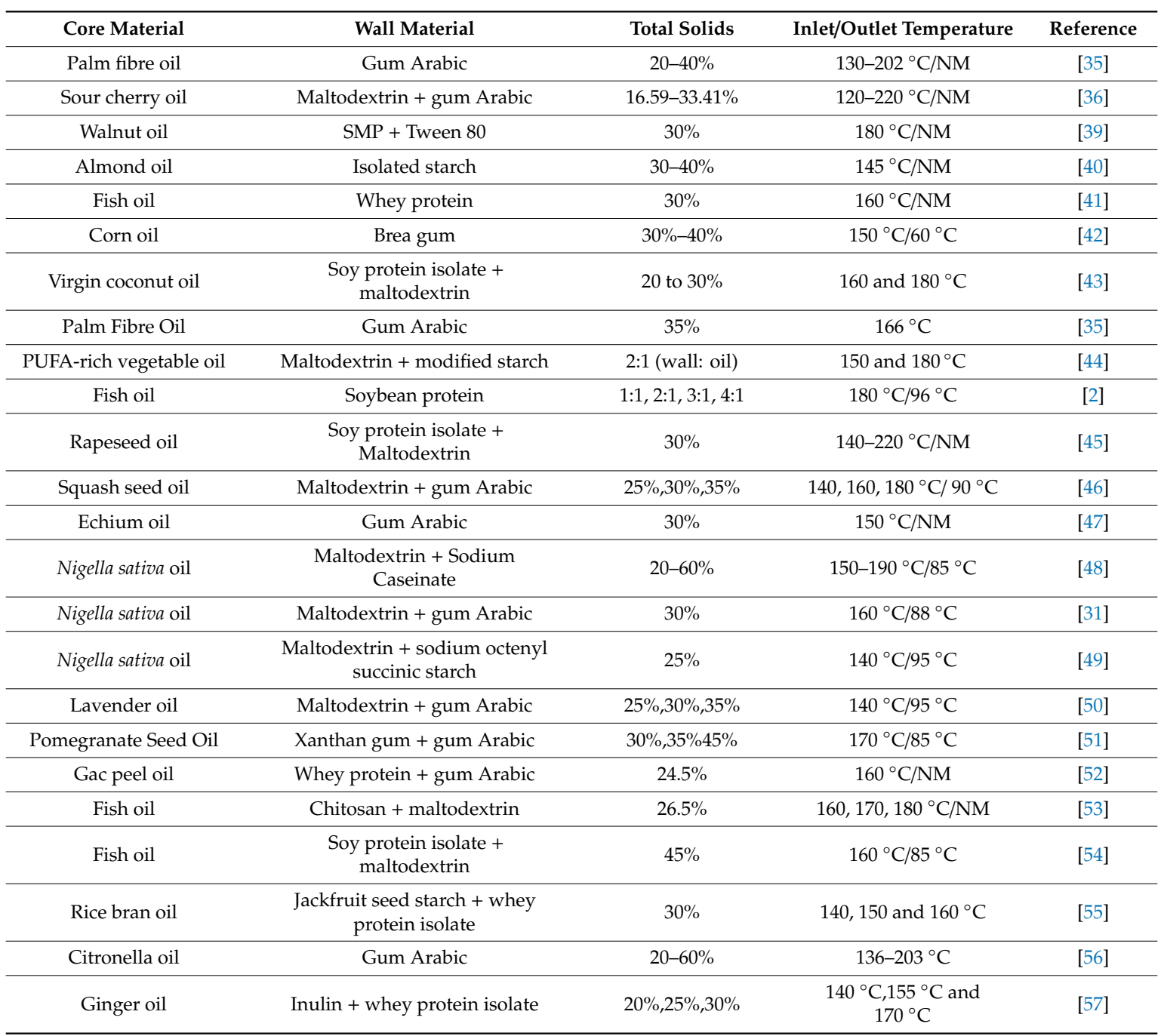

\subsection{Wall Materials}

The purpose of the wall materials is to act as a barrier between the core materials and any external factors that may cause their deterioration, to inhibit premature interactions between the core material and other ingredients, to reduce the reactivity of the core material with regard to the external environment, to limit volatile losses, and also to enable controlled or sustained release under desired conditions [29]. 
Table 2 shows different types of wall materials used in spray drying of oils [58]. The selections of the encapsulation technique and wall materials are interdependent. Wall material is very important for the oil encapsulation stability and protection efficiency of the core compound. The wall material influences the emulsion stability and the characteristics of the resulting microcapsules $[59,60]$. An ideal wall material should be highly water soluble and of low viscosity, while also possessing film forming properties. In addition, wall materials should have sufficient emulsifying ability to produce stable emulsions prior to spray drying [29]. However, a wide variety of encapsulating materials have been used for the encapsulation of flavours and oils, including low molecular weight polysaccharides (starches, maltodextrins (MD), gum Arabic (GA) and corn syrups), lipids (mono and diglycerides) and proteins (casein, milk serum and gelatin), as well as new emerging biopolymers, such as Millard reaction products [61]. Mixing two or more agents together may result in favourable characteristics such as maximizing the encapsulation efficiency of spray-dried powders and having an excellent stability and droplet size distribution for the emulsions [39].

Table 2. Wall materials commonly used in the spray drying process.

\begin{tabular}{cc}
\hline Wall Material & Interest \\
\hline Maltodextrin $(\mathrm{DE}<20)$ & Film forming \\
Corn syrup solid $(\mathrm{DE}>20)$ & Film forming, reducability \\
Modified starch & Very good emulsifier \\
Gum Arabic & Emulsifier, film forming \\
Modified cellulose & Film forming \\
Gelatin & Emulsifier, film forming \\
Cyclodextrin & Encapsulant, emulsifier \\
Lecithin & Emulsifier \\
Whey protein & Good emulsifier \\
Hydrogenated fat & Barrier to oxygen and water \\
Chitosan & Carrier of drug delivery \\
\hline
\end{tabular}

\subsubsection{Carbohydrates}

Starches that have been oxidized or incorporated with lipophilic groups have generally been found to have good solubility and good emulsifying and oil retention properties with low viscosities at high solid concentrations. However, when these materials are used individually, they lack the interfacial properties needed for high encapsulation efficiency, and are thus blended with other encapsulating materials such as proteins or gums [60]. Improving the encapsulation properties of wall materials can be achieved by chemically modifying carbohydrates. For instance, some modified starches have surface active properties and are widely used in the process of encapsulation by spray-drying. Hydrolysed starch products are hydrophilic compounds, and thus have little affinity for hydrophobic flavours and oils $[62,63]$.

Maltodextrins are starch hydrolysates that are produced via partial hydrolysis of starch using either acidic or enzymatic processes. Maltodextrin is popular in food processing, because it is inexpensive, nutritious, bland in flavour (non-sweet), highly soluble in cold water, and provides good flavour protection against oxidation. Maltodextrin has been proven to improve the oxidative stability of encapsulated oils, and is the most proper alternative for Arabic gum [29]. Maltodextrin provides a strong barrier against oxidation of core materials and protects against external factors [64]. The properties of the maltodextrin phase are also crucial in determining the rheological behaviour of the final product [65]. The carrier has advantages and disadvantages in terms of properties, costs and encapsulation efficiency. Different maltodextrins are classified into grades based on their dextrose equivalent (DE) value, which signifies the degree of hydrolysis of the starch molecule, and is directly linked to reducing sugar production. Maltodextrin with dextrose equivalent values of 10, 20, and 30 has desirable physical properties, and the particles have a smooth spherical surface [66,67]. Maltodextrins have been shown to be excellent thermal defenders, vital for protecting the integrity of anthocyanins 
during their encapsulation. A combination of proteins with different carbohydrates as wall materials, a blend of maltodextrin and sodium caseinate achieved a high encapsulation efficiency of some oils [32].

\subsubsection{Gums}

Gums are usually applied during the encapsulation process for film forming due to their ability to stabilize the emulsions. One of the most frequently used gums is acacia gum, known as gum Arabic (GA), which has many desirable properties, such as its emulsification properties. GA is a polymer consisting of D-glucuronic acid, L-rhamnose, D-galactose, and L-arabinose, with almost $2 \%$ protein $[68,69]$. GA has functional properties including as an emulsifier, flavouring agent, humectant, thickener, surface-finishing agent and for retarding sugar crystallization [69]. GA is the most used gum in encapsulation technology, but suffers from restricted availability, high cost, and inability to prevent oxidation [60]. Several studies have reported the application of gum Arabic for the encapsulation of oils such as fish oil [70], kenaf seed oil [71], and palm fibre oil [35].

\subsubsection{Proteins}

Proteins are excellent wall materials for encapsulation using spray drying due to their functional properties. Moreover, proteins provide high binding ability for flavour and oil compounds [29]. Proteins, in particular whey protein and sodium caseinate, have been studied as oil encapsulates due to their amphiphilic characteristics, which are caused by a hydrophilic group and a hydrophobic (or lipophilic) group, as well as their high diffusivity, which leads to better distribution around the enclosed oil surface [72,73]. There are several proteins or protein-containing isolates that have been applied for oil encapsulation, including soy, whey, casein and lecithin. A prevalent combination of oil encapsulation by spray drying is blend-based proteins, gums, and carbohydrates, in which the protein portion behaves as an emulsifier and carbohydrates act as the matrix-forming material. Specifically, soy or whey protein with maltodextrins are frequently applied, generally due to the variety of maltodextrins DE [74]. Among dairy proteins, sodium caseinate is preferred over other proteins due to its high solubility in water, emulsifying properties with oil and rapid formation of interfacial films and excellent surface activity [75]. Sodium caseinate has been reported to be the most effective emulsion stabilizer for fats. Sodium caseinate has been used alone or in blends with other wall materials to encapsulate a variety of volatile and non-volatile oils [76]. Research on the use of sodium caseinate as a wall material reports that it demonstrates good encapsulating properties, especially when used in combination with carbohydrates [77]. Sodium caseinate mixed with sunflower oil resulted in high encapsulation efficiency which was $99 \%$ in powder form [78]. According to Rosida et al. [79], using sodium caseinate to produce a non-dairy creamer resulted in a stable emulsion with white colour and significantly affected the protein content, giving a taste of milk (milk-sense). The mixture was concentrated and provided a white colour and stable emulsion when added to drinks or coffee.

Lecithin has been successfully used for the production of several encapsulated oils as an emulsifying agent to ensure the stability of the feeding emulsions before spray drying, for example, linseed oil [80] and kenaf seed oil [81]. Due to its lack of emulsifying properties, oil retention, and emulsion stability resulting from using maltodextrin alone as wall material, the addition of soy lecithin and carboxymethyl cellulose (CMC) improves encapsulation efficiency and oxidative stability [82].

\section{Applications of Encapsulated Oils in Food}

Consumer demand for healthy foods is growing rapidly due to scientific evidence that they improve human health. Furthermore, due to public concern about health, the demand for a healthy diet is increasing with the aim of reducing mortality and improving life quality. In general, the major difficulty in producing healthy oils for food applications is associated with the susceptibility of oils to oxidation. Several factors cause rapid oxidative degradation of food products that contain oils, including light, heat, and oxygen. Food deterioration caused by fatty acids limits the applications of some oils in food products, for example fish oil, which affects the texture, flavour, aroma, colour, 
and shelf-life of the product [83]. These drawbacks can be resolved via the encapsulation process of the oils to produce a stable powder with highly favourable properties. A wide range of seed and marine oils have been applied in food manufacturing to obtain functional food products with stable properties in the final product (Table 3). Examples of foods recently produced using encapsulated oils include dairy and non-dairy products, meat products, pastries, soups, etc. Several previous studies have reported the same limitation when applying fish oil and vegetable oils in food production, in that they are highly susceptible to oxidation. In addition, fortifying foods with some oils, particularly marine oils, is challenging due to their unpleasant taste, which could be overcome by applying the microencapsulation technique and masking the fishy taste. Moreover, replacing fats in some products with healthy sources of encapsulated oils is an area of interest for both manufacturers and consumers. Researchers have successfully incorporated encapsulated oils in various food products and observed higher oxidative stability, and high sensory acceptability for the products (Table 3).

Converting the liquids into a powdered encapsulated form can improved the stability and flow properties of the product during processing and handling. This technique may involve numerous types of functional oils for use as functional food ingredients [15]. 
Table 3. Applications of encapsulated oils using the spray drying technique in several functional food products.

\begin{tabular}{|c|c|c|c|c|}
\hline Encapsulated Oil & Product & Oil Source & Results & Reference \\
\hline Fish oil & Burger & Marine & $\begin{array}{l}\text { Burgers with microencapsulated fish oil showed the best scores for sensory traits and were stable during storage, } \\
\text { and the thermal behaviour of the microparticles was similar before and after incorporation into the cookies. }\end{array}$ & [84] \\
\hline Palm oil & Milk powder & Vegetable & $\begin{array}{l}\begin{array}{l}\text { The powders were easily soluble in water with low and non-hygroscopic moisture and low cohesiveness, } \\
\text { which correspond to good flowability. }\end{array}\end{array}$ & [85] \\
\hline Chia oil & Cookies & Seed & $\begin{array}{l}\text { Partial substitution of margarine by microencapsulated chia seed oil at } 15 \mathrm{wt} . \% \text { showed the best scores for } \\
\text { sensory evaluation. }\end{array}$ & [86] \\
\hline Flaxseed oil & Breads & Seed & $\begin{array}{l}\text { Breads fortified with microencapsulated flaxseed oil showed lower peroxide index and higher } \alpha \text {-linolenic acid value } \\
\text { and helps preserve sensory properties compared to breads fortified with free flaxseed oil. }\end{array}$ & [87] \\
\hline Canola oil & Non-dairy powder & Seed & Sodium caseinate and lactose via the Maillard reaction improved the encapsulation efficiency of oil up to $95.2 \%$. & [88] \\
\hline Shrimp oil & Biscuits & Marine & Biscuits fortified with $6 \%$ microencapsulated shrimp oil were stored in the dark to ensure their oxidative stability. & [89] \\
\hline Fish oil & $\begin{array}{l}\text { Chicken } \\
\text { nuggets }\end{array}$ & Marine & $\begin{array}{l}\text { Chicken nuggets enriched with microencapsulated fish oil showed no difference from control samples with respect to } \\
\text { sensory attributes, and lower levels of lipid and protein oxidation were found microencapsulated fish oil. }\end{array}$ & [90] \\
\hline Astaxanthin oil & Powder-based product & Marine & $\begin{array}{l}\text { The encapsulation efficiency of astaxanthin powder was higher than } 90 \% \text {, the bioaccessebility of the reconstitution was } \\
\text { around } 80 \% \text {, and it was stable under storage conditions. }\end{array}$ & [91] \\
\hline Rapeseed oil & Yoghurt & Seed & Yoghurt matrix with microcapsules presented high acceptability of appearance and showed stability for 30 days. & [92] \\
\hline Flaxseed oil & Chicken sausages & Seed & $\begin{array}{l}\begin{array}{l}\text { Spray-dried flaxseed oil formulations had lower values for cook loss and behaved differently during heating than the } \\
\text { other formulations. }\end{array}\end{array}$ & [93] \\
\hline Nigella sativa oil & Non-dairy creamer & Seed & $\begin{array}{l}\text { Microencapsulated oil demonstrated desired properties with high sensory acceptability for the revealed that developed } \\
\text { non-dairy creamer. }\end{array}$ & [94] \\
\hline Fish oil & Sausages & Marine & $\begin{array}{l}\text { Fish oil microcapsules in cooked and dry-cured meat products labelled as "source of omega-3 fatty acids", } \\
\text { overall quality of the meat products enriched seems not to be impaired after storing. }\end{array}$ & [95] \\
\hline Nigella sativa oil & Yoghurt & Seed & $\begin{array}{c}\text { High stability of thymoquinone and proper chemical and sensory properties for yoghurt with Nigella sativa seeds } \\
\text { oil microcapsules. }\end{array}$ & [49] \\
\hline Fish oil & Sausage & Marine & The lipid oxidation increased, lipid reformulation increased MUFAs and n-3 PUFAs levels with highest TBARS values. & [96] \\
\hline $\begin{array}{l}\text { Tigernut, chia and } \\
\text { linseed oils }\end{array}$ & Pâtés & Vegetable oils & $\begin{array}{l}\text { Pâtés with microencapsulated oils showed modified fatty acid composition, decreasing the total amount of SFA and } \\
\text { increasing PUFA (chia and linseed pâtés) or MUFA contents (tigernut pâtés). }\end{array}$ & [97] \\
\hline Chia oil & Burgers & Seed & $\begin{array}{l}\text { Microparticles of chia oil increased the terpenic volatiles and were characterized by the descriptors herbal and pleasant } \\
\text { aroma and ideal texture with liking scores for sensory evaluation. }\end{array}$ & [98] \\
\hline Fish oil & Chicken sausages & Marine & $\begin{array}{l}\text { The sausages with the addition of microcapsules was characterized by higher values on the smell and consistency } \\
\text { parameters with better results in the sensory evaluation. }\end{array}$ & [99] \\
\hline Fish oil & $\begin{array}{l}\text { Soup } \\
\text { powder }\end{array}$ & Marine & $\begin{array}{c}\text { The fortified soup powder of microencapsulated fish oil scored high in terms of sensory acceptance, } \\
\text { proving its acceptability. }\end{array}$ & {$[100]$} \\
\hline Catfish oil & Mushroom cream soup & Marine & Best physical characteristics of instant mushroom cream soup were reached with the addition of microcapsules at $3.6 \%$. & [101] \\
\hline
\end{tabular}




\section{Conclusions}

Vegetable oils contain health promoting lipids with biological and functional properties. These oils are prone to oxidation, instability, and degradation due to the high content of unsaturated fatty acids. Converting the oils into a powder enhances their oxidative stability and allows alternative use of the ingredients. Selection of an appropriate encapsulation technique depends on the characteristics of the oil (core) compounds, the level of stability of the encapsulated oil under storage and processing conditions, the characteristics of the food components, the production cost, and the maximum encapsulation efficiency in the powder. The spray drying technique is an essential processing technology that is applied in many functional food, nutraceutical and pharmaceutical products. However, optimizing the conditions is highly recommended for the production of stable and high-quality encapsulated oils. In addition, there has recently been remarkable demand for functional foods enriched with bioactive compounds, including encapsulated functional oils from plants and marine life, which have successfully been launched into the market. Therefore, further investigations should be carried out to develop innovative materials and techniques in order to produce novel products fortified with encapsulated functional oil ingredients in the near future.

Funding: This research received no external funding.

Acknowledgments: The authors would like to thank the Faculty of Food Science and Technology, Universiti Putra Malaysia.

Conflicts of Interest: The authors declare no conflict of interest.

\section{References}

1. Marrelli, M.; Statti, G.; Conforti, F. A Review of Biologically Active Natural Products from Mediterranean Wild Edible Plants: Benefits in the Treatment of Obesity and Its Related Disorders. Molecules 2020, 25, 649. [CrossRef] [PubMed]

2. Di Giorgio, L.; Salgado, P.R.; Mauri, A.N. Encapsulation of Fish Oil in Soybean Protein Particles by Emulsification and Spray Drying. Food Hydrocoll. 2019, 87, 891-901. [CrossRef]

3. Eratte, D.; Dowling, K.; Barrow, C.J.; Adhikari, B. Recent Advances in the Microencapsulation of Omega-3 Oil and Probiotic Bacteria through Complex Coacervation: A Review. Trends Food Sci. Technol. 2018, 71, 121-131. [CrossRef]

4. Ojagh, S.M.; Hasani, S. Characteristics and Oxidative Stability of Fish Oil Nano-Liposomes and Its Application in Functional Bread. J. Food Meas. Charact. 2018, 12, 1084-1092. [CrossRef]

5. Fang, Z.; Bhandari, B. Encapsulation of Polyphenols-A Review. Trends Food Sci. Technol. 2010, 21, 510-523. [CrossRef]

6. Agnihotri, N.; Mishra, R.; Goda, C.; Arora, M. Microencapsulation—A Novel Approach in Drug Delivery: A Review. Indo Glob. J. Pharm. Sci. 2012, 2, 1-20.

7. Aguiar, J.; Estevinho, B.N.; Santos, L. Microencapsulation of Natural Antioxidants for Food ApplicationThe Specific Case of Coffee Antioxidants-A Review. Trends Food Sci. Technol. 2016, 58, 21-39. [CrossRef]

8. Lozano-Vazquez, G.; Lobato-Calleros, C.; Escalona-Buendia, H.; Chavez, G.; Alvarez-Ramirez, J.; Vernon-Carter, E.J. Effect of the Weight Ratio of Alginate-Modified Tapioca Starch on the Physicochemical Properties and Release Kinetics of Chlorogenic Acid Containing Beads. Food Hydrocoll. 2015, 48, 301-311. [CrossRef]

9. Geranpour, M.; Assadpour, E.; Jafari, S.M. Recent Advances in the Spray Drying Encapsulation of Essential Fatty Acids and Functional Oils. Trends Food Sci. Technol. 2020, 102, 71-90. [CrossRef]

10. Amstad, E. Capsules: Their Past and Opportunities for Their Future; ACS Publications: Washington, DC, USA, 2017.

11. Estevinho, B.N.; Rocha, F. Application of Biopolymers in Microencapsulation Processes. In Biopolymers for Food Design; Elsevier: Amsterdam, The Netherlands, 2018; pp. 191-222.

12. Zuidam, N.J.; Nedović, V. Encapsulation Technologies for Active Food Ingredients and Food Processing; Springer: Berlin/Heidelberg, Germany, 2010.

13. Zheng, X.; Wu, F.; Hong, Y.; Shen, L.; Lin, X.; Feng, Y. Developments in Taste-Masking Techniques for Traditional Chinese Medicines. Pharmaceutics 2018, 10, 157. [CrossRef] 
14. Ahn, J.-H.; Kim, Y.-P.; Lee, Y.-M.; Seo, E.-M.; Lee, K.-W.; Kim, H.-S. Optimization of Microencapsulation of Seed Oil by Response Surface Methodology. Food Chem. 2008, 107, 98-105. [CrossRef]

15. Jafari, S.M.; Assadpoor, E.; He, Y.; Bhandari, B. Encapsulation Efficiency of Food Flavours and Oils during Spray Drying. Dry. Technol. 2008, 26, 816-835. [CrossRef]

16. Kolanowski, W.; Ziolkowski, M.; Weißbrodt, J.; Kunz, B.; Laufenberg, G. Microencapsulation of Fish Oil by Spray Drying-Impact on Oxidative Stability. Part 1. Eur. Food Res. Technol. 2006, 222, 336-342. [CrossRef]

17. Bilia, A.R.; Guccione, C.; Isacchi, B.; Righeschi, C.; Firenzuoli, F.; Bergonzi, M.C. Essential Oils Loaded in Nanosystems: A Developing Strategy for a Successful Therapeutic Approach. Evid. Based Complement. Altern. Med. 2014, 2014, 14. [CrossRef] [PubMed]

18. Bakry, A.M.; Abbas, S.; Ali, B.; Majeed, H.; Abouelwafa, M.Y.; Mousa, A.; Liang, L. Microencapsulation of Oils: A Comprehensive Review of Benefits, Techniques, and Applications. Compr. Rev. Food Sci. Food Saf. 2016, 15, 143-182. [CrossRef]

19. Gupta, S.; Khan, S.; Muzafar, M.; Kushwaha, M.; Yadav, A.K.; Gupta, A.P. Encapsulation: Entrapping Essential Oil/Flavors/Aromas in Food. In Encapsulations; Elsevier: Amsterdam, The Netherlands, 2016; pp. 229-268.

20. Manaf, M.A.; Subuki, I.; Jai, J.; Raslan, R.; Mustapa, A.N. Encapsulation of Volatile Citronella Essential Oil by Coacervation: Efficiency and Release Study. In IOP Conference Series: Materials Science and Engineering; IOP Publishing: Bristol, UK, 2018; p. 12072.

21. Encina, C.; Márquez-Ruiz, G.; Holgado, F.; Giménez, B.; Vergara, C.; Robert, P. Effect of Spray-Drying with Organic Solvents on the Encapsulation, Release and Stability of Fish Oil. Food Chem. 2018, 263, $283-291$. [CrossRef]

22. Melgosa, R.; Benito-Román, Ó.; Sanz, M.T.; de Paz, E.; Beltrán, S. Omega-3 Encapsulation by PGSS-Drying and Conventional Drying Methods. Particle Characterization and Oxidative Stability. Food Chem. 2019, 270, 138-148. [CrossRef]

23. Mohammed, N.K.; Meor Hussin, A.S.; Tan, C.P.; Abdul Manap, M.Y.; Alhelli, A.M. Quality Changes of Microencapsulated Nigella sativa Oil upon Accelerated Storage. Int. J. Food Prop. 2017, 20, S2395-S2408. [CrossRef]

24. Da Veiga, R.D.S.; Aparecida Da Silva-Buzanello, R.; Corso, M.P.; Canan, C. Essential Oils Microencapsulated Obtained by Spray Drying: A Review. J. Essent. Oil Res. 2019, 31, 457-473. [CrossRef]

25. Pellicer, J.A.; Fortea, M.I.; Trabal, J.; Rodríguez-López, M.I.; Gabaldón, J.A.; Núñez-Delicado, E. Stability of Microencapsulated Strawberry Flavour by Spray Drying, Freeze Drying and Fluid Bed. Powder Technol. 2019, 347, 179-185. [CrossRef]

26. Costa, S.S.; Machado, B.A.S.; Martin, A.R.; Bagnara, F.; Ragadalli, S.A.; Alves, A.R.C. Drying by Spray Drying in the Food Industry: Micro-Encapsulation, Process Parameters and Main Carriers Used. Afr. J. Food Sci. 2015, 9, 462-470.

27. Ng, S.; Jessie, L.L.; Tan, C.; Long, K.; Nyam, K. Effect of Accelerated Storage on Microencapsulated Kenaf Seed Oil. J. Am. Oil Chem. Soc. 2013, 90, 1023-1029. [CrossRef]

28. Schuck, P.; Dolivet, A.; Méjean, S.; Zhu, P.; Blanchard, E.; Jeantet, R. Drying by Desorption: A Tool to Determine Spray Drying Parameters. J. Food Eng. 2009, 94, 199-204. [CrossRef]

29. Gharsallaoui, A.; Roudaut, G.; Chambin, O.; Voilley, A.; Saurel, R. Applications of Spray-Drying in Microencapsulation of Food Ingredients: An Overview. Food Res. Int. 2007, 40, 1107-1121. [CrossRef]

30. Sosnik, A.; Seremeta, K.P. Advantages and Challenges of the Spray-Drying Technology for the Production of Pure Drug Particles and Drug-Loaded Polymeric Carriers. Adv. Colloid Interface Sci. 2015, 223, 40-54. [CrossRef]

31. Edris, A.E.; Kalemba, D.; Adamiec, J.; Piątkowski, M. Microencapsulation of Nigella sativa Oleoresin by Spray Drying for Food and Nutraceutical Applications. Food Chem. 2016, 204, 326-333. [CrossRef]

32. Munin, A.; Edwards-Lévy, F. Encapsulation of Natural Polyphenolic Compounds; A Review. Pharmaceutics 2011, 3, 793-829. [CrossRef]

33. Tumbas Šaponjac, V.; Čanadanović-Brunet, J.; Ćetković, G.; Jakišić, M.; Djilas, S.; Vulić, J.; Stajčić, S. Encapsulation of Beetroot Pomace Extract: RSM Optimization, Storage and Gastrointestinal Stability. Molecules 2016, 21, 584. [CrossRef] 
34. Pellicer, J.A.; Fortea, M.I.; Trabal, J.; Rodríguez-López, M.I.; Carazo-Díaz, C.; Gabaldón, J.A.; Núñez-Delicado, E. Optimization of the Microencapsulation of Synthetic Strawberry Flavour with Different Blends of Encapsulating Agents Using Spray Drying. Powder Technol. 2018, 338, 591-598. [CrossRef]

35. Carmona, P.A.O.; Garcia, L.C.; de Aquino Ribeiro, J.A.; Valadares, L.F.; de Figueiredo Marçal, A.; de França, L.F.; Mendonça, S. Effect of Solids Content and Spray-Drying Operating Conditions on the Carotenoids Microencapsulation from Pressed Palm Fiber Oil Extracted with Supercritical $\mathrm{CO}_{2}$. Food Bioprocess. Technol. 2018, 11, 1703-1718. [CrossRef]

36. Başyiğit, B.; Sağlam, H.; Kandemir, Ş.; Karaaslan, A.; Karaaslan, M. Microencapsulation of Sour Cherry Oil by Spray Drying: Evaluation of Physical Morphology, Thermal Properties, Storage Stability, and Antimicrobial Activity. Powder Technol. 2020, 364, 654-663. [CrossRef]

37. Frascareli, E.C.; Silva, V.M.; Tonon, R.V.; Hubinger, M.D. Effect of Process Conditions on the Microencapsulation of Coffee Oil by Spray Drying. Food Bioprod. Process. 2012, 90, 413-424. [CrossRef]

38. Ng, S.-K.; Choong, Y.-H.; Tan, C.-P.; Long, K.; Nyam, K.-L. Effect of Total Solids Content in Feed Emulsion on the Physical Properties and Oxidative Stability of Microencapsulated Kenaf Seed Oil. LWT-Food Sci. Technol. 2014, 58, 627-632. [CrossRef]

39. Shamaei, S.; Seiiedlou, S.S.; Aghbashlo, M.; Tsotsas, E.; Kharaghani, A. Microencapsulation of Walnut Oil by Spray Drying: Effects of Wall Material and Drying Conditions on Physicochemical Properties of Microcapsules. Innov. Food Sci. Emerg. Technol. 2017, 39, 101-112. [CrossRef]

40. Hoyos-Leyva, J.D.; Bello-Perez, L.A.; Agama-Acevedo, J.E.; Alvarez-Ramirez, J.; Jaramillo-Echeverry, L.M. Characterization of Spray Drying Microencapsulation of Almond Oil into Taro Starch Spherical Aggregates. LWT 2019, 101, 526-533. [CrossRef]

41. Lavanya, M.N.; Kathiravan, T.; Moses, J.A.; Anandharamakrishnan, C. Influence of Spray-Drying Conditions on Microencapsulation of Fish Oil and Chia Oil. Dry. Technol. 2019, 279-292. [CrossRef]

42. Castel, V.; Rubiolo, A.C.; Carrara, C.R. Brea Gum as Wall Material in the Microencapsulation of Corn Oil by Spray Drying: Effect of Inulin Addition. Food Res. Int. 2018, 103, 76-83. [CrossRef]

43. Quispe, N.B.P.; Chaves, M.A.; Dos Santos, A.F.; Bastos, T.D.S.; Castro, S.S. Microencapsulation of Virgin Coconut Oil by Spray Drying/Microencapsulação de Óleo de Coco Virgem Por Spray Spray. Braz. J. Dev. 2020, 6, 1510-1529. [CrossRef]

44. Vélez-Erazo, E.M.; Consoli, L.; Hubinger, M.D. Spray Drying of Mono- and Double-Layer Emulsions of PUFA-Rich Vegetable Oil Homogenized by Ultrasound. Dry. Technol. 2020, 1-14. [CrossRef]

45. Linke, A.; Linke, T.; Hinrichs, J.; Kohlus, R. Factors Determining the Surface Oil Concentration of Encapsulated Lipid Particles-Impact of the Spray Drying Conditions. Dry. Technol. 2019, 1-14. [CrossRef]

46. Pino, J.A.; Sosa-Moguel, O.; Sauri-Duch, E.; Cuevas-Glory, L. Microencapsulation of Winter Squash (Cucurbita moschata Duchesne) Seed Oil by Spray Drying. J. Food Process. Preserv. 2019, 43, e14136. [CrossRef]

47. Comunian, T.A.; Favaro, L.F.; Thomazini, M.; Pallone, E.M.J.A.; do Amaral Sobral, P.J.; de Castro, I.A.; Favaro-Trindade, C.S. Echium Oil with Oxidative Stability Increased by Emulsion Preparation in the Presence of the Phenolic Compound Sinapic Acid Followed by Dehydration by Spray and Freeze Drying Processes. J. Food Sci. Technol. 2019, 56, 1155-1164. [CrossRef] [PubMed]

48. Mohammed, N.K.; Tan, C.P.; Manap, Y.A.; Alhelli, A.M.; Hussin, A.S.M. Process Conditions of Spray Drying Microencapsulation of Nigella sativa Oil. Powder Technol. 2017, 315, 1-14. [CrossRef]

49. Abedi, A.; Rismanchi, M.; Shahdoostkhany, M.; Mohammadi, A.; Hosseini, H. Microencapsulation of Nigella sativa Seeds Oil Containing Thymoquinone by Spray-drying for Functional Yogurt Production. Int. J. Food Sci. Technol. 2016, 51, 2280-2289. [CrossRef]

50. Burhan, A.M.; Abdel-Hamid, S.M.; Soliman, M.E.; Sammour, O.A. Optimisation of the Microencapsulation of Lavender Oil by Spray Drying. J. Microencapsul. 2019, 36, 250-266. [CrossRef]

51. Yekdane, N.; Goli, S.A.H. Effect of Pomegranate Juice on Characteristics and Oxidative Stability of Microencapsulated Pomegranate Seed Oil Using Spray Drying. Food Bioprocess. Technol. 2019, 12, 1614-1625. [CrossRef]

52. Chuyen, H.V.; Roach, P.D.; Golding, J.B.; Parks, S.E.; Nguyen, M.H. Encapsulation of Carotenoid-Rich Oil from Gac Peel: Optimisation of the Encapsulating Process Using a Spray Drier and the Storage Stability of Encapsulated Powder. Powder Technol. 2019, 344, 373-379. [CrossRef] 
53. Chang, H.W.; Tan, T.B.; Tan, P.Y.; Nehdi, I.A.; Sbihi, H.M.; Tan, C.P. Microencapsulation of Fish Oil-in-Water Emulsion Using Thiol-Modified $\beta$-Lactoglobulin Fibrils-Chitosan Complex. J. Food Eng. 2020, 264, 109680. [CrossRef]

54. Linke, A.; Weiss, J.; Kohlus, R. Oxidation Rate of the Non-Encapsulated-and Encapsulated Oil and Their Contribution to the Overall Oxidation of Microencapsulated Fish Oil Particles. Food Res. Int. 2020, 127, 108705. [CrossRef]

55. Murali, S.; Kar, A.; Patel, A.S.; Mohapatra, D.; Krishnakumar, P. Optimization of Rice Bran Oil Encapsulation Using Jackfruit Seed Starch-Whey Protein Isolate Blend as Wall Material and Its Characterization. Int. J. Food Eng. 2017, 13, 4. [CrossRef]

56. Yingngam, B.; Kacha, W.; Rungseevijitprapa, W.; Sudta, P.; Prasitpuriprecha, C.; Brantner, A. Response Surface Optimization of Spray-Dried Citronella Oil Microcapsules with Reduced Volatility and Irritation for Cosmetic Textile Uses. Powder Technol. 2019, 355, 372-385. [CrossRef]

57. De Barros Fernandes, R.V.; Botrel, D.A.; Silva, E.K.; Pereira, C.G.; Do Carmo, E.L.; De Abreu Dessimoni, A.L.; Borges, S.V. Microencapsulated Ginger Oil Properties: Influence of Operating Parameters. Dry. Technol. 2017, 35, 1098-1107. [CrossRef]

58. Madene, A.; Jacquot, M.; Scher, J.; Desobry, S. Flavour Encapsulation and Controlled Release-A Review. Int. J. Food Sci. Technol. 2006, 41, 1-21. [CrossRef]

59. Turchiuli, C.; Lemarié, N.; Cuvelier, M.-E.; Dumoulin, E. Production of Fine Emulsions at Pilot Scale for Oil Compounds Encapsulation. J. Food Eng. 2013, 115, 452-458. [CrossRef]

60. Carneiro, H.C.F.; Tonon, R.V.; Grosso, C.R.F.; Hubinger, M.D. Encapsulation Efficiency and Oxidative Stability of Flaxseed Oil Microencapsulated by Spray Drying Using Different Combinations of Wall Materials. J. Food Eng. 2013, 115, 443-451. [CrossRef]

61. Augustin, M.A.; Sanguansri, L. Encapsulation of Bioactives. In Food Materials Science; Springer: Berlin/Heidelberg, Germany, 2008; pp. 577-601.

62. Verdalet-Guzmán, I.; Martínez-Ortiz, L.; Martínez-Bustos, F. Characterization of New Sources of Derivative Starches as Wall Materials of Essential Oil by Spray Drying. Food Sci. Technol. 2013, 33, 757-764. [CrossRef]

63. Wang, X.; Yuan, Y.; Yue, T. The Application of Starch-based Ingredients in Flavor Encapsulation. Starch Stärke 2015, 67, 225-236. [CrossRef]

64. Sanchez, V.; Baeza, R.; Galmarini, M.V.; Zamora, M.C.; Chirife, J. Freeze-Drying Encapsulation of Red Wine Polyphenols in an Amorphous Matrix of Maltodextrin. Food Bioprocess. Technol. 2013, 6, 1350-1354. [CrossRef]

65. Hadnađev, M.; Hadnađev, T.D.; Torbica, A.; Dokić, L.; Pajin, B.; Krstonošić, V. Rheological Properties of Maltodextrin Based Fat-Reduced Confectionery Spread Systems. Procedia Food Sci. 2011, 1, 62-67. [CrossRef]

66. Mulcahy, E.M.; Mulvihill, D.M.; O’Mahony, J.A. Physicochemical Properties of Whey Protein Conjugated with Starch Hydrolysis Products of Different Dextrose Equivalent Values. Int. Dairy J. 2016, 53, 20-28. [CrossRef]

67. Da Silva Carvalho, A.G.; da Costa Machado, M.T.; da Silva, V.M.; Sartoratto, A.; Rodrigues, R.A.F.; Hubinger, M.D. Physical Properties and Morphology of Spray Dried Microparticles Containing Anthocyanins of Jussara (Euterpe edulis Martius) Extract. Powder Technol. 2016, 294, 421-428. [CrossRef]

68. Daoub, R.M.A.; Elmubarak, A.H.; Misran, M.; Hassan, E.A.; Osman, M.E. Characterization and Functional Properties of Some Natural Acacia Gums. J. Saudi Soc. Agric. Sci. 2018, 17, 241-249. [CrossRef]

69. Dauqan, E.; Abdullah, A. Utilization of Gum Arabic for Industries and Human Health. Am. J. Appl. Sci. 2013, 10, 1270-1279. [CrossRef]

70. Dos Santos Vaucher, A.C.; Dias, P.C.M.; Coimbra, P.T.; Dos Santos, I.M.C.; Marreto, R.N.; Dellamora-Ortiz, G.M.; De Freitas, O.; Ramos, M.F.S. Microencapsulation of Fish Oil by Casein-Pectin Complexes and Gum Arabic Microparticles: Oxidative Stabilization. J. Microencapsul. 2019, 36, 459-473. [CrossRef] [PubMed]

71. Chew, S.C.; Tan, C.P.; Nyam, K.L. Microencapsulation of Refined Kenaf (Hibiscus cannabinus, L.) Seed Oil by Spray Drying Using $\beta$-Cyclodextrin/Gum Arabic/Sodium Caseinate. J. Food Eng. 2018, 237, 78-85. [CrossRef]

72. Hogan, S.A.; McNamee, B.F.; O’Riordan, E.D.; O'Sullivan, M. Emulsification and Microencapsulation Properties of Sodium Caseinate/Carbohydrate Blends. Int. Dairy J. 2001, 11, 137-144. [CrossRef]

73. Fäldt, P.; Bergenståhl, B. Fat Encapsulation in Spray-Dried Food Powders. J. Am. Oil Chem. Soc. 1995, 72, 171-176. [CrossRef] 
74. Labuschagne, P. Impact of Wall Material Physicochemical Characteristics on the Stability of Encapsulated Phytochemicals: A Review. Food Res. Int. 2018, 107, 227-247. [CrossRef]

75. Zhang, Y.; Pan, K.; Zhong, Q. Eugenol Nanoencapsulated by Sodium Caseinate: Physical, Antimicrobial, and Biophysical Properties. Food Biophys. 2018, 13, 37-48. [CrossRef]

76. Ixtaina, V.Y.; Julio, L.M.; Wagner, J.R.; Nolasco, S.M.; Tomás, M.C. Physicochemical Characterization and Stability of Chia Oil Microencapsulated with Sodium Caseinate and Lactose by Spray-Drying. Powder Technol. 2015, 271, 26-34. [CrossRef]

77. Shi, L.; Beamer, S.K.; Yang, H.; Jaczynski, J. Micro-Emulsification/Encapsulation of Krill Oil by Complex Coacervation with Krill Protein Isolated Using Isoelectric Solubilization/Precipitation. Food Chem. 2018, 244, 284-291. [CrossRef] [PubMed]

78. Domian, E.; Sułek, A.; Cenkier, J.; Kerschke, A. Influence of Agglomeration on Physical Characteristics and Oxidative Stability of Spray-Dried Oil Powder with Milk Protein and Trehalose Wall Material. J. Food Eng. 2014, 125, 34-43. [CrossRef]

79. Rosida, D.F.; Mulyani, T.; Septalia, L.R. A Comparative Study of Non-Dairy Cream Based on the Type of Leguminosae Protein Source in Terms of Physico Chemical Properties and Organoleptic. Agric. Agric. Sci. Proced. 2016, 9, 431-439. [CrossRef]

80. Gallardo, G.; Guida, L.; Martinez, V.; López, M.C.; Bernhardt, D.; Blasco, R.; Pedroza-Islas, R.; Hermida, L.G. Microencapsulation of Linseed Oil by Spray Drying for Functional Food Application. Food Res. Int. 2013, 52, 473-482. [CrossRef]

81. Razmkhah, S.; Tan, C.; Long, K.; Nyam, K. Quality Changes and Antioxidant Properties of Microencapsulated Kenaf (Hibiscus cannabinus, L.) Seed Oil during Accelerated Storage. J. Am. Oil Chem. Soc. 2013, 90, 1859-1867. [CrossRef]

82. Calvo, P.; Hernández, T.; Lozano, M.; González-Gómez, D. Microencapsulation of Extra-virgin Olive Oil by Spray-drying: Influence of Wall Material and Olive Quality. Eur. J. Lipid Sci. Technol. 2010, 112, 852-858. [CrossRef]

83. Ye, A.; Cui, J.; Taneja, A.; Zhu, X.; Singh, H. Evaluation of Processed Cheese Fortified with Fish Oil Emulsion. Food Res. Int. 2009, 42, 1093-1098. [CrossRef]

84. Aquilani, C.; Pérez-Palacios, T.; Sirtori, F.; Jiménez-Martín, E.; Antequera, T.; Franci, O.; Acciaioli, A.; Bozzi, R.; Pugliese, C. Enrichment of Cinta Senese Burgers with Omega-3 Fatty Acids. Effect of Type of Addition and Storage Conditions on Quality Characteristics. Grasas Aceites 2018, 69, 235. [CrossRef]

85. Samsu, Z.; Zahir, A.Z.M. Production of Oil Palm Milk Powder by Spray Drying Technique. Mater. Today Proc. 2020. [CrossRef]

86. Venturini, L.H.; Moreira, T.F.M.; da Silva, T.B.V.; de Almeida, M.M.C.; Francisco, C.R.L.; de Oliveira, A.; de Campos, S.S.; Bilck, A.P.; de Souza Leone, R.; Tanamati, A.A.C. Partial Substitution of Margarine by Microencapsulated Chia Seeds Oil in the Formulation of Cookies. Food Bioprocess. Technol. 2019, 12, 77-87. [CrossRef]

87. Beikzadeh, S.; Shojaee-Aliabadi, S.; Dadkhodazade, E.; Sheidaei, Z.; Abedi, A.-S.; Mirmoghtadaie, L.; Hosseini, S.M. Comparison of Properties of Breads Enriched with Omega-3 Oil Encapsulated in $\beta$-Glucan and Sacharomyces cerevisiae Yeast Cells. Appl. Food Biotechnol. 2019, 1, 11-20.

88. Li, K.; Woo, M.W.; Patel, H.; Selomulya, C. Enhancing the Stability of Protein-Polysaccharides Emulsions via Maillard Reaction for Better Oil Encapsulation in Spray-Dried Powders by PH Adjustment. Food Hydrocoll. 2017, 69, 121-131. [CrossRef]

89. Takeungwongtrakul, S.; Benjakul, S. Biscuits Fortified with Micro-Encapsulated Shrimp Oil: Characteristics and Storage Stability. J. Food Sci. Technol. 2017, 54, 1126-1136. [CrossRef] [PubMed]

90. Pérez-Palacios, T.; Ruiz-Carrascal, J.; Jiménez-Martín, E.; Solomando, J.C.; Antequera, T. Improving the Lipid Profile of Ready-to-cook Meat Products by Addition of Omega-3 Microcapsules: Effect on Oxidation and Sensory Analysis. J. Sci. Food Agric. 2018, 98, 5302-5312. [CrossRef] [PubMed]

91. Burgos-Díaz, C.; Opazo-Navarrete, M.; Soto-Añual, M.; Leal-Calderón, F.; Bustamante, M. Food-Grade Pickering Emulsion as a Novel Astaxanthin Encapsulation System for Making Powder-Based Products: Evaluation of Astaxanthin Stability during Processing, Storage, and Its Bioaccessibility. Food Res. Int. 2020, 134, 109244. [CrossRef] [PubMed] 
92. De Moura, S.C.S.R.; Schettini, G.N.; Garcia, A.O.; Gallina, D.A.; Alvim, I.D.; Hubinger, M.D. Stability of Hibiscus Extract Encapsulated by Ionic Gelation Incorporated in Yogurt. Food Bioprocess. Technol. 2019, 12, 1500-1515. [CrossRef]

93. Bolger, Z.; Brunton, N.P.; Monahan, F.J. Impact of Inclusion of Flaxseed Oil (Pre-Emulsified or Encapsulated) on the Physical Characteristics of Chicken Sausages. J. Food Eng. 2018, 230, 39-48. [CrossRef]

94. Mohammed, N.K.; Tan, C.P.; Manap, M.Y.A.; Muhialdin, B.J.; Hussin, A.S.M. Production of Functional Non-Dairy Creamer Using Nigella Sativa Oil via Fluidized Bed Coating Technology. Food Bioprocess. Technol. 2019, 8, 1352-1365. [CrossRef]

95. Solomando, J.C.; Antequera, T.; Perez-Palacios, T. Evaluating the Use of Fish Oil Microcapsules as Omega-3 Vehicle in Cooked and Dry-Cured Sausages as Affected by Their Processing, Storage and Cooking. Meat Sci. 2020, 162, 108031. [CrossRef]

96. Domínguez, R.; Pateiro, M.; Agregán, R.; Lorenzo, J.M. Effect of the Partial Replacement of Pork Backfat by Microencapsulated Fish Oil or Mixed Fish and Olive Oil on the Quality of Frankfurter Type Sausage. J. Food Sci. Technol. 2017, 54, 26-37. [CrossRef]

97. Vargas-Ramella, M.; Pateiro, M.; Barba, F.J.; Franco, D.; Campagnol, P.C.B.; Munekata, P.E.S.; Tomasevic, I.; Domínguez, R.; Lorenzo, J.M. Microencapsulation of Healthier Oils to Enhance the Physicochemical and Nutritional Properties of Deer Pâté. LWT 2020, 125, 109223. [CrossRef]

98. Heck, R.T.; Fagundes, M.B.; Cichoski, A.J.; de Menezes, C.R.; Barin, J.S.; Lorenzo, J.M.; Wagner, R.; Campagnol, P.C.B. Volatile Compounds and Sensory Profile of Burgers with 50\% Fat Replacement by Microparticles of Chia Oil Enriched with Rosemary. Meat Sci. 2019, 148, 164-170. [CrossRef] [PubMed]

99. Stangierski, J.; Rezler, R.; Kawecki, K.; Peplińska, B. Effect of Microencapsulated Fish Oil Powder on Selected Quality Characteristics of Chicken Sausages. J. Sci. Food Agric. 2020, 100, 2043-2051. [CrossRef] [PubMed]

100. Kumar, L.R.G.; Jayathilakan, K.; Sarika, K.; Priya, E.R.; Greeshma, S.S.; Sultana, K.; Tejpal, C.S.; Mathew, S. Effect of Plectranthus Amboinicus Leaf Extract on the Quality Attributes of Microencapsulated Fish Oil Fortified Soup Powder; Society of Fisheries Technologists: Willingdon Island, India, 2019.

101. Hastarini, E.; Napitupulu, R.J.; Poernomo, S.H. Characteristics of Instant Mushroom Cream Soup Enriched with Catfish Oil Microcapsules. In IOP Conference Series: Earth and Environmental Science; IOP Publishing: Bristol, UK, 2019; p. 12005.

(C) 2020 by the authors. Licensee MDPI, Basel, Switzerland. This article is an open access article distributed under the terms and conditions of the Creative Commons Attribution (CC BY) license (http://creativecommons.org/licenses/by/4.0/). 